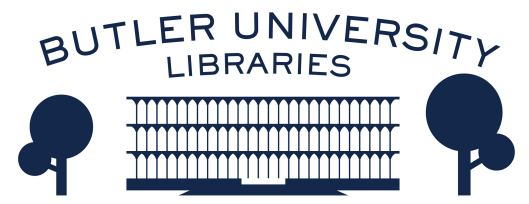

Journal of Hindu-Christian Studies

Volume 21

Article 19

January 2008

\title{
Book Review: "The Crisis of Secularism in India"
}

Chad Bauman

cbauman@butler.edu

Follow this and additional works at: https://digitalcommons.butler.edu/jhcs

Part of the Religion Commons

\section{Recommended Citation}

Bauman, Chad (2008) "Book Review: "The Crisis of Secularism in India"," Journal of Hindu-Christian Studies: Vol. 21, Article 19.

Available at: https://doi.org/10.7825/2164-6279.1418

The Journal of Hindu-Christian Studies is a publication of the Society for Hindu-Christian Studies. The digital version is made available by Digital Commons @ Butler University. For questions about the Journal or the Society, please contact cbauman@butler.edu. For more information about Digital Commons @ Butler University, please contact digitalscholarship@butler.edu. 
behalf.

Chapter seven is the climax of this book. It focuses entirely on 1944-1945 and the reasons for Neill's departure from India. Daughrity describes the "conspiracy of silence" that surrounded Neill's departure from India and Bishop Richard Holloway's breaking of that silence. Daughrity's contribution is a careful historical reconstruction of what happened. Among Neill's many external and internal conflicts, Indian nationalism and his sadomasochistic tendencies chiefly contributed to his departure from India.

The final chapter offers a brief conclusion. Daughrity shows that despite Neill's undoubted guilt regarding the accusations that led to his downfall, his widespread popularity was such that his tenure as bishop is seen as the golden age in Tinnevelly's history.

With three useful appendices of primary sources on Neill, a list of archives consulted and interviews undertaken, further bibliographic information and an index, Daughrity rounds off his volume.

The author's 'conflict thesis' seems overstretched initially, but the evidence accumulates as the book develops, climaxing in chapter seven by which time the thesis becomes quite compelling. He traces the origins and development of this internal conflict within Neill and shows how this conflict marks his career and friendships, with serious consequences.
Although the author believed the examination of the possible causes of Neill's sadism to be outside of his remit, some obvious connections with Neill's school experiences could have been highlighted. Despite the necessary historical exposition of Neill's downfall, one sympathises with those conspirators of silence who were concerned to emphasise Neill's great achievements for which he is remembered. These achievements do feature, but by using the conflict thesis as an interpretive tool they are occasionally recast in a more negative light. One feels that Neill's deep spirituality and faithfulness to Christ, as well as his honesty and sustained courage, are rather under-represented and overshadowed.

The sporadic repetition of quotations and the occasional typographical errors aside, Daughrity has produced a commendable historical biography. Of the three contributions he claims to make to scholarship he succeeds particularly well in his first two, whilst the third is underdeveloped. Neill's life, "at once so promising, yet so hamstrung by conflict" (5) was indeed the enigma Daughrity described. One hopes that Daughrity, or another so capable, undertakes a complementary volume on the second half of the life of Bishop Stephen Neill.

Adam Dodds

University of Otago, New Zealand

\section{The Crisis of Secularism in India. Edited by Anuradha Dingwaney Needham and Rajeswari Sunder Rajan. Durham: Duke University Press, 2007, xii + 411.}

THE essays in this volume address the "crisis of secularism" in India, a crisis which, the editors suggest, emerged during the Emergency and culminated in the 2002 Gujarat violence (1). While this particular "crisis" may be an Indian one, the editors argue that it is but one manifestation of a tension which lies at the very heart of democratic secularism, a tension between the need for national unity and the desire to preserve and allow for religious difference. By virtue of their electoral politics, secular democracies place the majority in a position of dominance over minorities such that in the quest for national unity religious minorities are left with an undesirable choice: relinquish their distinctive identities or risk being seen as traitors, spoilers, or foreigners.

The volume will be of interest to readers of $J H C S$ because of the way these issues affect Christianity and Hindu-Christian relations in India. While some of the essays address the interaction of Hindus and Christians directly, in other cases, the relevance to such topics is of the tangential variety. For example, the first section 
on "Secularism's Historical Background," with essays by Shabnum Tejani, Paula Richman and V. Geetha, and Sunil Khilnani, describe and debate the nature and utility of secular visions offered by well known figures such as Ambedkar, Gandhi, and Nehru, and lesserknown intellectuals like E. V. Ramasami.

Similarly, authors of essays in the second section, "Secularism and Democracy" (Ashis Nandy, Nivedita Menon, Partha Chatterjee, Gyanendra Pandey, and Gyan Prakash) return to the tension noted in my opening paragraph. These five essays ask whether secularism and democracy are truly compatible and, if so, how the relationship of the state and minorities in India might be more productively envisioned and enacted.

The volume's third section contains essays which examine "Sites of Secularism," that is, the various contexts in which debates about secularism and religious identity are played out in India today, whether in history textbooks (as in Romila Thapar's essay); the news media (as in Arvind Rajagopal's), or film (as in the essays by Shyam Benegal and Ravi Vasudevan).

In the fourth section, "Secularism and Personal Law," essays by Upendra Baxi, Flavia Agnes and Akeel Bigrami focus on what is arguably the most controversial and contested idiosyncrasy of Indian secularism: the existence of religion-specific personal law codes alongside the universal civil law code.

The two essays of the final section, "Conversion," are of direct relevance to those who study the interaction of Hindus and Christians in India. In the first, "Literacy and Conversion in the Discourse of Hindu Nationalism," Gauri Viswanathan analyzes the complicated interrelatedness of literacy, education, and anti-conversion polemics. Viswanathan explores the Indian reaction, in 1998, when Amartya Sen won the Nobel prize in economics. While most of the country was euphoric, some Hindu nationalists, Vishwa Hindu Parishad president Ashok Singhal most prominent among them, criticized Sen's view of human development, which insisted that "all forms of human deprivation such as hunger, malnutrition, and illiteracy be brought within the purview of public policy" (333). According to Singhal, insisting on the development of literacy in India as a fundamental freedom would necessarily require the help of NGOs, which would mean greater Christian missionary investment in India, and-as a natural outgrowth-more conversions.

Singhal's was without question a marginal voice, too radical even for many within prominent Hindu nationalist organizations. Nevertheless, Viswanathan argues that Singhal's response to Sen's work exposed an anxiety among many Hindu nationallists that development and cultural integrity are at odds with one another (particularly when the development is engineered by "foreign" NGOs). Such a view rests, Viswanathan asserts, on an elitist conception of the poor and illiterate as gullible and easily manipulated, and incapable of choosing a religious faith (for other than material interests). It also rests on the assumption that conversion necessarily entails a kind of cultural violence, a view made more plausible by the history of colonial conquest in India and the putative foreignness of Christianity, and one linked to a long history of missionary education in India which focused on those peoples to whom the government could not (or would not) provide decent education: tribal groups and the lower castes in rural areas. Viswanathan acknowledges the fact that literacy, particularly literacy in English, does hold the potential to actuate cultural change by offering to those who possess it a new "form of access to the world" (346). Nevertheless, she maintains the controversial position that if "missionaries give people services they would otherwise not have had, no one has a right to restrict their activities, particularly when there are no other state-supported or private initiatives" (346).

The second essay in the section on conversion is Sumit Sarkar's "Christian Conversions, Hindutva, and Secularism." Sarkar interrogates three assumptions that he believes inform Hindu nationalists' distaste for Christian conversion. The first of these is that Hinduism is a "uniquely nonproselytizing religion" (357). Questioning this assumption, Sarkar asks rhetorically where all the Indian Buddhists have gone, and how it is that nonIndian peoples of Southeast Asia have become Hindu.

The second assumption Sarkar discusses is 
that Christianity is a religion of foreign origin. "The charge persists," Sarkar asserts, "despite the fact that the origins of Christianity in one part of India (Kerala and Tamilnadu) go back to the early centuries of the Common Era, preceding, incidentally, the conversion of England to Christianity and indeed the formation of most living forms of Hindu traditions" and Sikhism (360). It is only because of the perceived collusion of Christianity and British colonialism, Sarkar contends, that the notion survives.

The third assumption that Sarkar critiques is the conflation of secularism and mere opposition to communalism. Opposition to communalism is a noble pursuit, says Sarkar, but if secularism is just another way of speaking of national unity then it is unavoidable that the desire for unity will overshadow the preservation of diversities. On the contrary, Sarkar contends, secularism "ought to represent a set of human values that would remain indispensable even if Indian unity broke down" (366).

It seems to me today that any worthy investigation of Hindu-Christian relations in India must place those relations in the larger context of long-standing debates about secularism and democracy in the religiously diverse Indian state. This volume, therefore, is indispensable to those working on the topic, both for the articles of more indirect relevance, and for these excellent concluding essays.

Chad Bauman

Butler University

\section{The Quest for Postmodern Ethics: A Phenomenological Comparison of the Philosophies of Martin Heidigger and Sri Aurobindo Ghose. R. Brad Bannon. Bangalore: Dharmaram Publications, 2007, $269+\mathrm{xi}$} pages.

DESPITE Brad Bannon's assurance that he has "tried to write this book to students and "nonacademics" (15), The Quest for Postmodern Ethics is not for the faint of heart. The fruit of Bannon's philosophical studies at Dharmaram Vidya Kshetram in Bangalore, the work attempts to move beyond mere "philosophyology" or comparative philosophy to a more profound "discussion "with" or "playing forth" of great philosophies as he and his readers think through these major issues for themselves (6-7). In form, it draws on the work of the German existentialist Martin Heidigger as its "starting point" and of the neo-Advaitin Aurobindo Ghose as a "complement." But Bannon's more basic intent is to construct an "ab-ground" or creative space for post-modern moral reasoning around questions of character development and conscience formation in the contemporary world. Only a rigorously non-foundationalist "aretological" or virtue-based ethics, developed through authentic enquiry, continual reformulation and ever-widening circles of concern, Bannon suggests, will move religions and cultures beyond an inauthentic reliance upon teleological (goal-driven) or deontological (rulebased) ethical systems.

In his predilection for meta-discourse and neologisms, Bannon reveals great affinity with Raimon Panikkar; indeed, Panikkar's distinctive understandings of "advaita" "ecosophy" and "consmotheandric experience" are invoked at several key junctures of the argument. Also like Panikkar, however, Bannon offers far more than a new technical vocabulary. In the first four chapters, he explores what Heidigger referred to as the "ontological difference" between Being itself and the lived experience of "a being." In articulating his understanding of this being as "Dasein"- "Being-there" in space and time, "Being-with-Others" in mutually constitutive relations-Heidigger attempted to overcome the subject-object dualisms of Plato, Descartes and Kant. In so doing, Bannon argues, the great philosopher also moved toward and is met by Aurobindo's evolutionist advaita, which attempted to rescue a robust sense of individual identity and cosmic play (lila) from the purportedly world-denying monisms of Buddhism and classical Advaita. These two 